\title{
Regeneration of Nickel-Molybdenum Catalysts DN-3531 and Criterion 514 Used in Kerosene and Gas Oil Hydrotreating by Supercritical Carbon Dioxide Extraction
}

\author{
Ameer Abed Jaddoa1,2, Timur R. Bilalov ${ }^{1}{ }^{*}$, Farid M. Gumerov ${ }^{1}$, Farizan R. Gabitov ${ }^{1}$, \\ B. Le Neindre ${ }^{3}$ \\ ${ }^{1}$ Federal State Educational Institution of Higher Professional Education, Kazan National Research Technological \\ University, Kazan, Russia \\ ${ }^{2}$ University of Technology, Baghdad, Iraq \\ ${ }^{3}$ Université Paris 13, Sorbonne Paris Cité, Laboratoire des Sciences des Procédés et des Matériaux, CNRS, \\ Villetaneuse, France \\ Email: ${ }^{*}$ t.bilalov@yandex.ru
}

Received 25 June 2015; accepted 28 August 2015; published 1 September 2015

Copyright (C) 2015 by authors and Scientific Research Publishing Inc.

This work is licensed under the Creative Commons Attribution International License (CC BY).

http://creativecommons.org/licenses/by/4.0/

(c) (i) Open Access

\begin{abstract}
Results of research of supercritical fluid $\mathrm{CO}_{2}$-regeneration process of Nickel-Molybdenum Catalysts DN-3531 and Criterion 514 are given. Regeneration was carried out with the use of pure supercritical carbon dioxide and mixture of supercritical carbon dioxide and various polar cosolvents. Regeneration process is carried out along isotherms, in the temperature range of $323-383$ $\mathrm{K}$, at pressures of $P=20 \mathrm{MPa}$ and $30 \mathrm{MPa}$. Results of surface assessment of the catalyst samples regenerated show high effectiveness of suggested method.
\end{abstract}

\section{Keywords}

Supercritical Carbon Dioxide, Aluminum Oxide, Nickel-Molybdenum Catalyst, Regeneration

\section{Introduction}

During the last several years, many countries have imposed a reduction of sulfur level to 10 ppm in fuels, to mi-

\footnotetext{
"Corresponding author.
}

How to cite this paper: Jaddoa, A.A., Bilalov, T.R., Gumerov, F.M., Gabitov, F.R. and Neindre, B.L. (2015) Regeneration of Nickel-Molybdenum Catalysts DN-3531 and Criterion 514 Used in Kerosene and Gas Oil Hydrotreating by Supercritical Carbon Dioxide Extraction. International Journal of Analytical Mass Spectrometry and Chromatography, 3, 37-46. 
nimize harmful products from the combustion of fuel. In the European Union, the standard "Euro V”, which specifies a maximum of 10 ppm sulfur in diesel fuels for most road vehicles, has been applied since 2009. In Russia, the formal technical requirements for fuels were introduced by Government Decree No. 118, “Technical Regulation on requirements for automotive and aviation gasoline, diesel and marine fuel, jet fuel and heating oil.” Three automotive standards cover fuel quality: Type I (Euro 3), Type II (Euro 4) and Type III (Euro 5) with a sulfur content of 350 ppm, 50 ppm and 10 ppm, respectively. Delays in implementing national fuel quality standards vary across the country, according to the refineries, which must complete the necessary upgrades [1]. The quality of diesels in the US has been specified by ASTM D975, which covered seven qualities diesel fuel oils for different types of diesel engines. Since 2010, ultra-low sulfur diesel (ULSD) with a sulfur content of 15 ppm is the new standard for all on-road diesel fuel. Non-road diesel engine fuel, like railroad locomotive and marine diesel fuel, moves also to ULSD in 2014.

Sulfur is the most prevalent element in the oil after carbon and hydrogen. The average sulfur content varies from 0.03 wt\% to 7.89 wt\% in crude oil. The sulfur content of crude oil belongs to the following groups: free elemental sulfur; mercaptans and tiols (R-SH); hydrogen sulfide; sulfides; disulfides (R-S-S-R'); polysulfides (R-Sn-R'); thiophenes, and derivatives thereof, such as benzothiophene and dibenzothiophene.

In a typical catalytic hydro-treating unit, the feedstock is deaerated and mixed with hydrogen, preheated in heater, and then charged under pressure, through a fixed-bed catalytic reactor. In the reactor, sulfur, nitrogen and oxygen compounds in the feedstock are converted into hydrogen sulfide, ammonia and water, in the presence of catalyst. The main process variables characterizing the hydro-treating process are temperature, the total pressure of the reactor, the circulation rate of the hydrogen-bearing gas, the feed space velocity, and the catalyst activity [2] [3]. The space velocity is the ratio between the feed rates into the reactor, per hour, over the catalyst volume [4]. Increasing the temperature and the partial pressure of hydrogen increases the sulfur and nitrogen removal and the hydrogen consumption. Increasing pressure also leads to increase of the saturation of hydrogen and reduces the formation of coke [5].

The selection of optimum hydro-treating temperature depends on the quality of the feedstock, the process leading conditions, the loss of catalyst activity over time, and is located within 613 - $673 \mathrm{~K}$, for the compounds with boiling points within 503 - $633 \mathrm{~K}$, and 573 - $643 \mathrm{~K}$, the compounds with boiling points within 413 - $503 \mathrm{~K}$.

The hydro-desulfurization process is a catalytic process, which removes the organic sulfur from petroleum streams [6] by conversion to hydrogen sulfide gas, following the basic equations:

Ethanethiol: $\mathrm{C}_{2} \mathrm{H}_{5} \mathrm{SH}+\mathrm{H}_{2} \rightarrow \mathrm{C}_{2} \mathrm{H}_{6}+\mathrm{H}_{2} \mathrm{~S}$

Mercaptans: $\mathrm{RSH}+\mathrm{H}_{2} \rightarrow \mathrm{RH}+\mathrm{H}_{2} \mathrm{~S}$

Sulfides: $\mathrm{R}_{2} \mathrm{~S}+2 \mathrm{H}_{2} \rightarrow 2 \mathrm{RH}+\mathrm{H}_{2} \mathrm{~S}$

Disulfides: $\mathrm{R}_{2} \mathrm{~S}_{2}+3 \mathrm{H}_{2} \rightarrow 2 \mathrm{RH}+2 \mathrm{H}_{2} \mathrm{~S}$

Thiophenes: $\mathrm{RC}_{4} \mathrm{H}_{3} \mathrm{~S}+4 \mathrm{H}_{2} \rightarrow \mathrm{RC}_{4} \mathrm{H}_{9}+\mathrm{H}_{2} \mathrm{~S}$

The desulfurization reactions are exothermic and the heat of reaction ranges approximately from 2300 to 2400 $\mathrm{kJ} / \mathrm{m}^{3}$ of hydrogen [7]. On the other hand, sulfur can amalgamate with the nickel content in many metal alloys to form a eutectic alloy with low melting point, which can increase the lubricity. The process used to reduce the sulfur also reduces the lubricating properties of the fuel that can lead to accelerated corrosion in turbine fuel pumps.

The refining process that removes the sulfur also reduces the content of aromatic compounds and density of the fuel, resulting in a slight decrease in the energy content of about $1 \%$. This reduction in energy content may slightly reduce peak power and fuel economy. However, the reduction of aromatic content of diesel fuels is also relevant, because the aromatic hydrocarbons have low ethane number, contributing to the increase of vehicle emission (primarily the hydrocarbon and particulate matter).

The ease of desulfurization depends on the type of compounds. Sulfur in acyclic aliphatic sulfides (thioethers) and cyclic sulfides (thiols) are the easiest to remove [8]. On the other hand, sulfur in aromatic rings, such as thiophene and its benzologs for example: benzothiophene, dibenzothiophene and benzonaphthothiophene, is more resistant to removal sulfur by hydrodesulfurization [7] [9] [10].

The choice of catalysts for this process depends on the feedstock to be treated and the product required. Catalyst activity is determined by the target reaction components conversion rate. The higher activity of the catalyst, the higher space velocity the process may be carried out with to reach a great desulfurization depth.

Cobalt and molybdenum dispersed in a thin layer within the pore system of the alumina support are today generally used for the removal of sulfur, as they have proven to be very selective, easy to regenerate, and more 
tolerant of poisoning agents.

Since nitrogen is usually more difficult to remove from the feed stocks as sulfur, for removal of nitrogen, catalysts composed of nickel-molybdenum on alumina supports are more efficient than cobalt-molybdenum, because they have a higher hydrogenation activity, resulting in the same operating conditions, in a larger saturation of aromatic rings [11].

In this study, we test the use of a nickel-molybdenum catalyst supported on the alumina substrate [12]. Thus, hydro-treating processes are carried out with nickel-molybdenum catalyst, "Criterion 514" for kerosene hydro-treating and "DN3531" for gasoil hydro-treating; both catalysts are manufactured by "Criterion Catalyst and Technology". The main characteristics of these catalysts are shown in Table 1.

The catalyst activity decreases over time due to the increase in the deposition of coke on the catalyst surface. The decrease of the partial pressure of hydrogen, in the circulating gas, tightens the process conditions and facilitates the catalyst carbonization [13]. To recover its lost activity, the catalyst can be regenerated in-situ, biennially periodically. In the regeneration process, the deposits of coke and sulfur on the catalyst are burned in a controlled manner with a dilute stream of nitrogen-oxygen mixture, at a pressure of 2.4 to 2.6 MPa and a temperature in the reactor above $703 \mathrm{~K}$ [13].

This is followed by reduction of some of the compounds formed during the oxidation step, in a dilute hydrogen stream. During the oxidation, some of the sulfur on the catalyst is converted into sulfates and some metal sulfates are formed as the sulfidized catalyst is converted into the oxide form. These metal sulfates may be reduced by exposure to hydrogen at high pressure, in metal sulfides with liberation of sulfur dioxide. These reactions are highly exothermic, which may result in loss of catalyst activity or structural damage to the catalyst and the reactor.

The catalyst gradually "ages” due to recrystallization and surface structure changes, as well as due to adsorption of organometallic and other substances on the catalyst surface which block the active sites. In this case, the catalyst loses its activity and must be replaced with a new one [14].

An alternative to the process described above may be the regeneration of the catalyst by the supercritical fluid, which is described in this study. Table 2 shows a comparison of the conventional method and supercritical catalyst regeneration method [15].

The temperature of regeneration during the extraction with carbon dioxide is more than 5 times lower than the

Table 1. Characteristics of Dn-3531 and criterion 514 for kerosene and gasoil hydro-treating [12].

\begin{tabular}{|c|c|c|c|}
\hline Name of catalysts & Quality of indicators & Standard values & Scope of application \\
\hline \multirow{3}{*}{$\begin{array}{l}\text { "Criterion 514” } \\
\text { catalyst }\end{array}$} & Aluminum oxide content, $\mathrm{Al}_{2} \mathrm{O}_{3}$, wt\% & 89.5 & \multirow{3}{*}{$\begin{array}{c}\text { Protective layer of kerosene } \\
\text { hydrotreating catalyst }\end{array}$} \\
\hline & Molybdenum oxide content, $\mathrm{MoO}_{3}$, wt\% & 8.2 & \\
\hline & NiOoxidecontent, wt\% & 2.3 & \\
\hline \multirow{8}{*}{$\begin{array}{l}1.3 \text { and } 2.5 \text { mm sized } \\
\text { "DN 3531" catalyst }\end{array}$} & Alumino-silicate basis- $\mathrm{Al}_{2} \mathrm{O}_{3} / \mathrm{SiO}_{2}$, wt $\%$ & $55-75$ & \multirow{8}{*}{$\begin{array}{l}\text { Gasoil hydrotreating } \\
\text { catalyst }\end{array}$} \\
\hline & Molybdenum oxide, $\mathrm{MoO}_{3}$, wt\%, less than & 30 & \\
\hline & Phosphorous pentoxide, $\mathrm{P}_{2} \mathrm{O}_{5}$, wt $\%$, less than & 10 & \\
\hline & Nickel oxide, Ni, wt\%, less than & 6 & \\
\hline & Iron oxide, $\mathrm{Fe}_{2} \mathrm{O}_{3}$, wt $\%$ & $1-4$ & \\
\hline & Calcium oxide, $\mathrm{CaO}$, wt\% & $0-1$ & \\
\hline & Potassium oxide, $\mathrm{K}_{2} \mathrm{O}$, wt\% & $1-4$ & \\
\hline & Sodium oxide, $\mathrm{Na}_{2} \mathrm{O}$, wt $\%$ & $1-4$ & \\
\hline
\end{tabular}

Table 2. Comparison between traditional and SCF methods of regeneration.

\begin{tabular}{|c|c|c|}
\hline Method & Traditional regeneration process & SCF regeneration process \\
\hline Extractant & Ozone-air mixture & $\mathrm{CO}_{2}+$ co-solvent \\
\hline Temperature & $673-873 \mathrm{~K}$ & $323-383 \mathrm{~K}$ \\
\hline Pressure & $0.8-1.5 \mathrm{MPa}$ & $20-30 \mathrm{MPa}$ \\
\hline Process life & $30-50 h$ & $4-7 \mathrm{~h}$ \\
\hline Number of regeneration cycles & $3-4$ & $\geq 6-8$ \\
\hline
\end{tabular}


temperature of the conventional approach, which is one of the major advantages in terms of energy consumption. At temperatures lower, the catalyst does not deteriorate due to its "sintering", which can occur at higher temperatures. The process time is reduced, and the number of possible regeneration cycles increases. By the way, in the case of the regeneration process by supercritical carbon dioxide, it is not necessary to use alkaline water to neutralize the acid exhaust gas.

\section{Materials, Equipment, and Applied Research Methods}

The samples of spent catalyst regeneration that took place in the framework of this study were provided by the refinery "Taif-NK". Figure 1, and Table 3 and Table 4 show the results of thermal and thermo gravimetric studies of samples of the spent catalysts.

TG chart shows the reduction in the mass of the sample, along a solid line (1) starting at $100 \%$. FGD-mass change rate (2) is represented by a dash-dot line. The two lines illustrate how quickly the reduction of the sample mass was going on: rates have increased significantly in the temperature range from $303 \mathrm{~K}$ to $376 \mathrm{~K}$. The mass reduction rate has subsequently fallen sharply in the temperature range from $376 \mathrm{~K}$ to $593 \mathrm{~K}$, and has risen again in the temperature range from $593 \mathrm{~K}$ to $673 \mathrm{~K}$, and then fell again in the temperature range from $673 \mathrm{~K}$ to

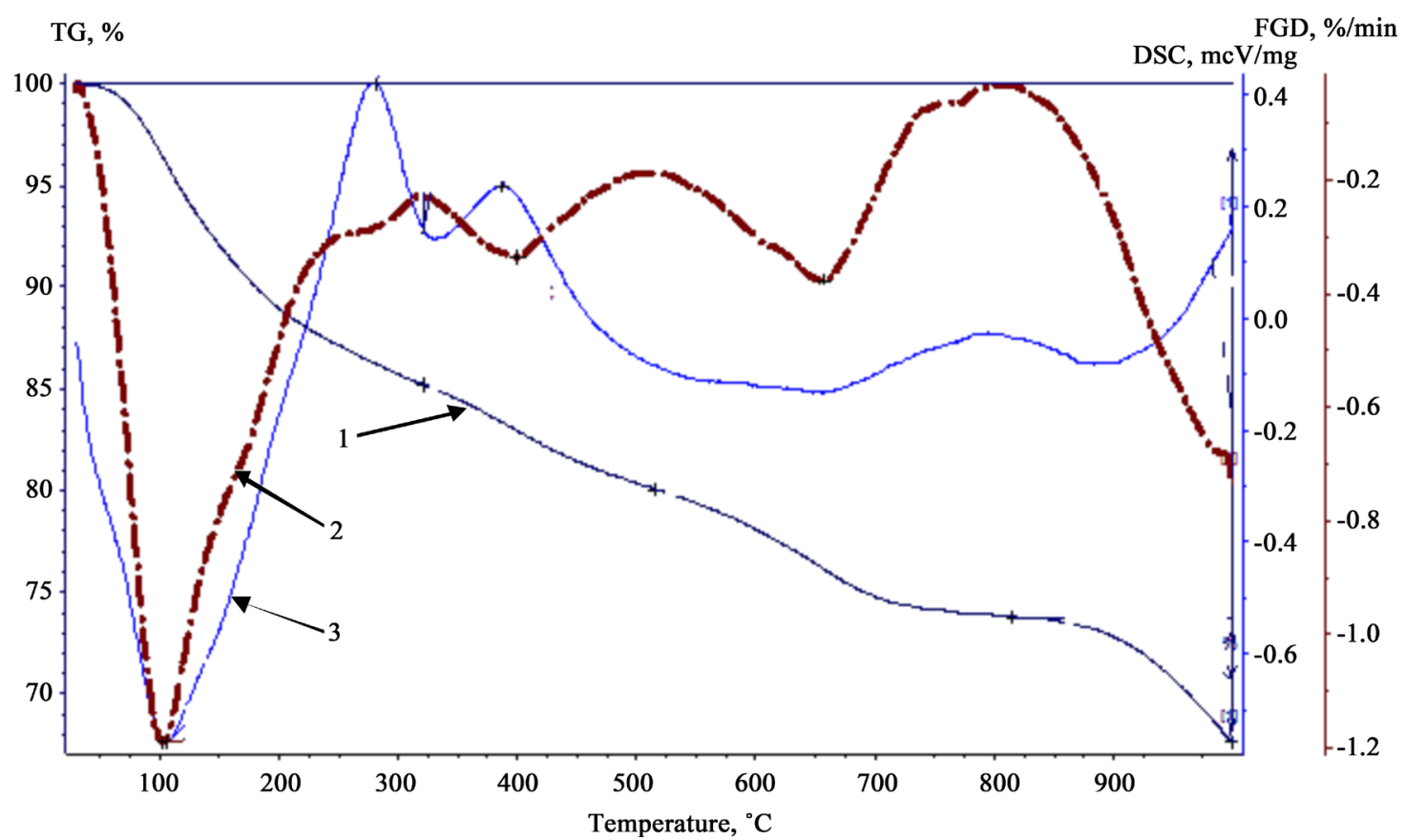

Figure 1. Thermal analysis of the nickel-molybdenum catalyst, DN-3531, for kerosene hydro-treater: (1) rate of sample mass loss (TG); (2) rate of sample mass loss (FGD); (3) observed thermal effects (DSC).

Table 3. Results of the study of the reduction of mass as a function of temperature, by the thermos-gravimetric method (TG-DTG).

\begin{tabular}{ccccc}
\hline Temperature range, $\mathrm{K}$ & $303-593$ & $593-788$ & $788-1088$ & $1088-1273$ \\
Maximum effect, $\mathrm{K}$ & $(376)$ & $(673)$ & $(930)$ & $(-)$ \\
Change in mass, wt\% & 14.79 & 5.15 & 6.27 & 6.15 \\
\hline
\end{tabular}

(-) no explicit thermal conversion maximum.

Table 4. Results of the study of thermal effects by differential scanning calorimetry (DSC).

\begin{tabular}{ccc} 
Temperature range, $\mathrm{K}$ & $303-498$ & $498-573$ \\
Maxima of thermal effects, K & $379(\downarrow)$ & $553(\uparrow)$ \\
\hline
\end{tabular}

$(\downarrow),(\uparrow)$ endothermic and exothermic effects respectively. 
$788 \mathrm{~K}$, has risen again in the temperature range from $788 \mathrm{~K}$ to $930 \mathrm{~K}$, then dropped to nearly zero, and increased again at the end.

Thus, according to the DSC data (solid line starting at 87), the following thermal effects were observed: the evaporation of the moisture accompanied by heat absorption (endothermic effect) occurred in the temperature range from $303 \mathrm{~K}$ to $498 \mathrm{~K}$. Two exothermic effects in the temperature range followed this from $498 \mathrm{~K}$ to $593 \mathrm{~K}$ and from $593 \mathrm{~K}$ to $823 \mathrm{~K}$ : corresponding to substances containing respectively carbon and sulfur, respectively, deposited on the catalyst, which were burned [14]-[16]. No significant exothermic and endothermic effects were observed at higher temperatures. The total mass loss of the sample represented $32.37 \%$ and $14.79 \%$ in the temperature range from $303 \mathrm{~K}$ to $593 \mathrm{~K}$.

The catalyst samples were regenerated in the plant shown in Figure 2, according to the following procedure.

The catalyst of this study, is placed in a metal basket, weighed with scales and introduced into the extractor, in the path of the fluid phase (extractant). Operating parameters of the process are set and regeneration process is carried out. Mass change of the catalyst sample is evaluated by weighing. The amount of carbon dioxide used for regeneration is also determined by the weight method.

This equipment also allows to conduct studies of the dependence of the solubility of pollutants components of the catalyst, conventionally taken as a model of coke, in pure and supercritical carbon dioxide.

One method to evaluate the efficiency of the regeneration processes is to determine the surface area of the catalyst samples regenerated according to the method described in [17] [18]. This method is a modification of the gas adsorption chromatography, wherein the column packing is itself the sample, and the mobile phase is a known mixture of an appropriated adsorbent and an inert gas.

A known mixture of nitrogen and helium $\left(12 \% \mathrm{~N}_{2}+88 \% \mathrm{He}\right)$ is passed from the gas cylinder through a filter-drier and is divided into two streams. One stream is sent to the relative outlet chamber of the thermal conductivity detector. The other stream is directed into a U-shaped tube, loaded with a catalyst sample therein, and then flows into the measuring chamber of the sensor. When the U-shaped tube with a catalyst is immersed in the Dewar vessel with liquid nitrogen, the nitrogen from the feed mixture is absorbed by the catalyst sample. When the absorption is complete, Dewar vessel was removed, and the nitrogen desorption begins. The absorption and desorption of nitrogen is observed on the recording potentiometer, which detects the signal from the thermal conductivity detector. The flow rate of the mixture is regulated by valves, and the pressure is measured by pressure gauge. The curves of both adsorption and desorption and the area under either one of these curves is a measure of the nitrogen adsorbed.

\section{Results and Discussions}

The process of regeneration of Dn-3531 and 514 Criterion hydrogenation catalysts has been studied experimentally

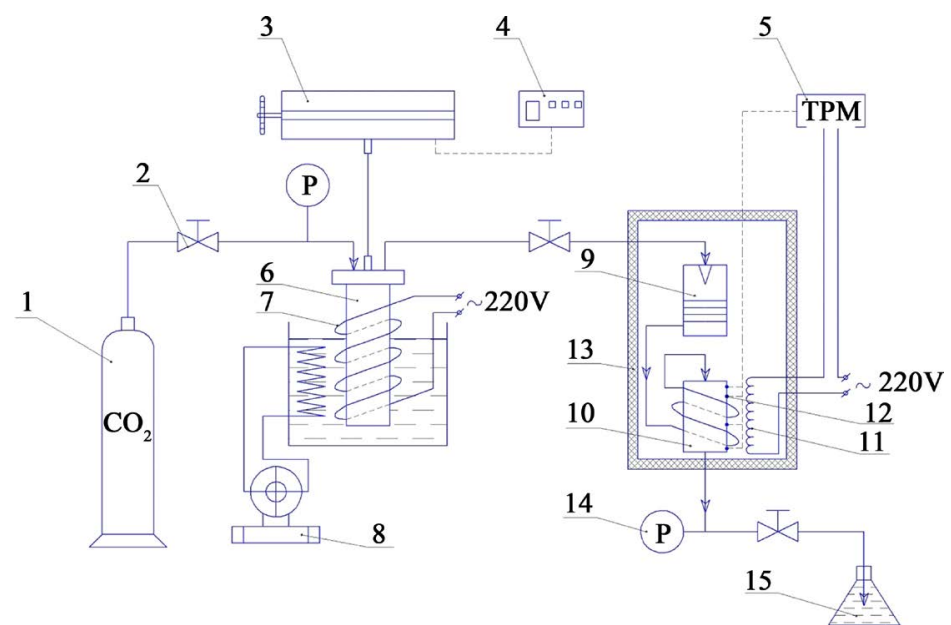

Figure 2. Schematic diagram of the experimental plant: (1) $\mathrm{CO}_{2}$ bottle, (2) valve, (3) weighing device, (4) weighing control panel, (5) “TPM-148” temperature controller and pressure indicator, (6) thermocompressor cell in cooler bath, (7) heater, (8) refrigerator, (9) co-solvent cell, (10) extraction cell, (11) heater of extraction cell, (13) thermal insulation, (12) thermocouples (4 sensors), (14) test pressure gauge, (15) vessel for collecting the extract. 
in the following manner. To ensure a high level of saturation of supercritical carbon dioxide with deactivating compounds, the mass flow of $\mathrm{CO}_{2}$ was calibrated in a preliminary study, in order to investigate the influence of the mass flow rate of supercritical $\mathrm{CO}_{2}$ on the change in mass of deactivated catalyst (Figure 3).

In the first series of experiments, the catalyst samples were regenerated using pure $\mathrm{CO}_{2}$. Regeneration process is carried out along isotherms, in the temperature range of 323 to $383 \mathrm{~K}$, at pressures of $P=20 \mathrm{MPa}$ and $30 \mathrm{MPa}$ (Figure 4). The graph shows that regeneration process is more efficient at $T=383.15 \mathrm{~K}$ and $P=30 \mathrm{MPa}$. In this case, a decrease $6.9 \mathrm{wt} \%$, in the initial mass of the catalyst is observed, indicating a significant potential for regeneration of the catalyst using the method under discussion.

A greater effect can be obtained by increasing the mass of carbon dioxide used in the method, the modification of operating parameters of the method and of the physical and chemical nature of the extractant. In the latter case, we consider the change of the extracting agent and, in addition, the use of a polar additive. The extraction with supercritical fluid, in the catalyst regeneration process, generally causes no reduction in the mass fraction of the active component, because the metals are nearly insoluble in the supercritical fluid media [19].

It is known that the dissolving capacity of non-polar carbon dioxide compared to polar substances is limited, which hinders the result in the development of certain technologies [19]. The dissolving ability and selectivity of the solvent are largely determined by the saturated vapor pressure of the solute. Adding polar co-solvents often leads to a significant increase in the solubility.

Since the forces of interaction between the co-solvent molecules and solutes are specific, it often results in improving the selectivity of the extraction process.

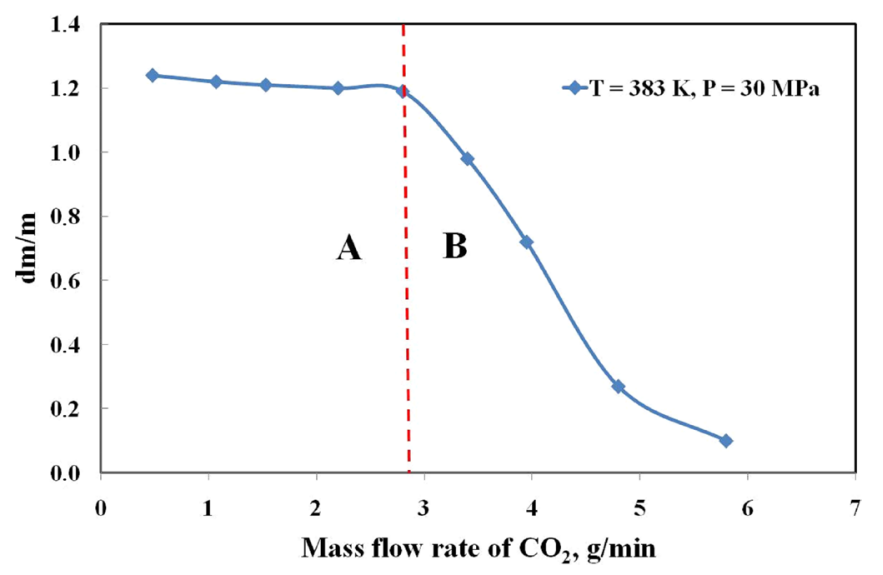

Figure 3. Changes in the mass of catalyst in relation to the mass flow rate of supercritical carbon dioxide at $T=383 \mathrm{~K}$ and $P=30 \mathrm{MPa}$.

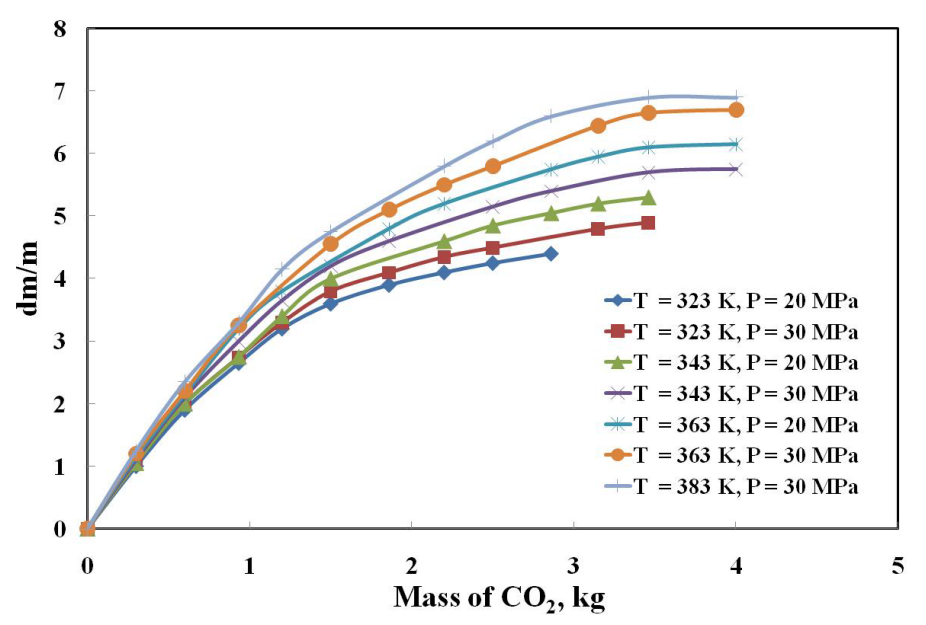

Figure 4. Change in the mass of nickel-molybdenum catalyst with respect to the mass flow of pure $\mathrm{SC}-\mathrm{CO}_{2}$. 
Studies [19]-[22] show that supercritical $\mathrm{CO}_{2}$ without a co-solvent dissolves slightly polar compounds, whereas the dissolving capacity is greatly increased by the addition of a co-solvent.

Addition of modifiers such as methanol, ethanol and other in a percentage ratio from $0.1 \mathrm{wt} \%$ to $20 \mathrm{wt} \%$ can be achieved before feeding the extractant into the extractor or directly in the extractor [19].

The comparison of the efficiency of the catalyst regeneration with pure supercritical carbon dioxide, and modified acetone, is shown in Figure 5. The figure shows that the addition of the co-solvent has significantly increased the capacity of $\mathrm{SC}-\mathrm{CO}_{2}$ to extract the poisoning compounds and thus intensify the catalyst regeneration process.

The addition of polar co-solvent to carbon dioxide increased the capacity to remove polar compounds included in the coke. However, it was necessary to determine the optimal physical and chemical nature of co-solvent, as well as the optimal concentration of polar additive in order to improve the result [19].

As in case with the flow of supercritical fluid solvent, different concentrations of co-solvent define different efficiencies of regeneration (Table 5, Figure 6).

Therefore, the catalyst regeneration process using supercritical carbon dioxide modified with the following polar additives was carried out under a second set of experiments:

- Dimethylsulphoxide (DMSO)

- Acetone

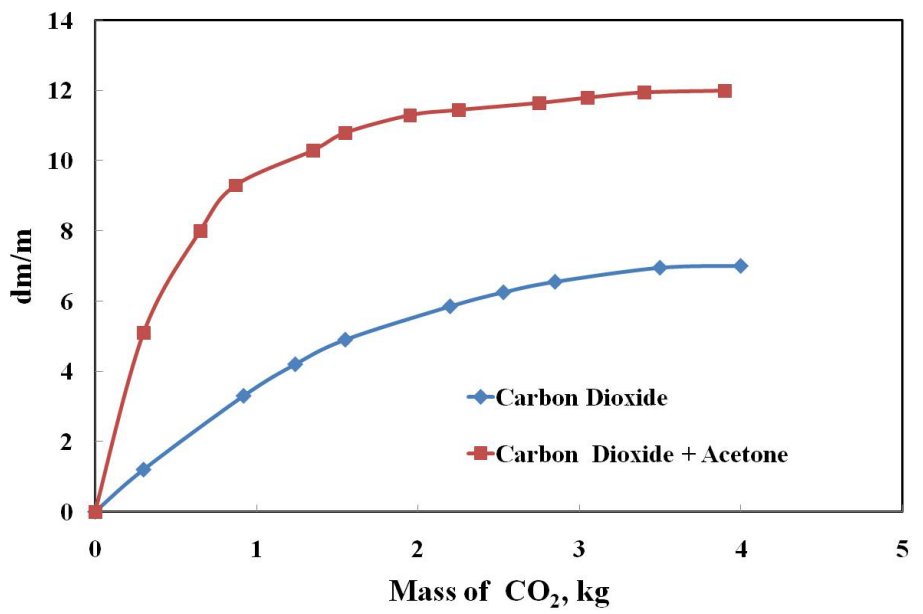

Figure 5. Variation in the mass of catalyst samples in function of the mass of the extraction medium (pure $\mathrm{CO}_{2}$ and $\mathrm{CO}_{2}+$ acetone) used in the regeneration process $(T=383 \mathrm{~K}, P=30 \mathrm{MPa})$.

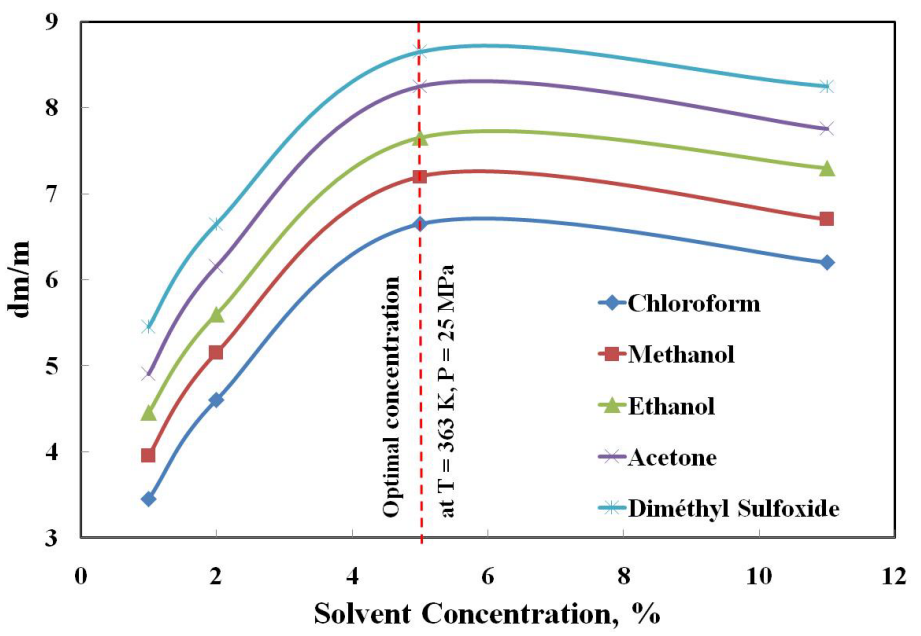

Figure 6. Change in the mass of catalyst samples in the extraction process of regeneration by super critical carbon dioxide ( $T=363 \mathrm{~K}, P=25 \mathrm{MPa}$ ), as a function of the concentration of various co-solvents. 
Table 5. Effect of the solvent concentration on the catalyst performance of the regeneration process.

\begin{tabular}{|c|c|c|c|}
\hline & \multicolumn{2}{|c|}{ Mass of solvent } & \multirow{2}{*}{ Percentage of efficiency } \\
\hline & $\mathrm{CO}_{2}, \mathrm{~g}$ & Dimethylsulphoxide, g & \\
\hline Experiment -1- & 1340 & $15.72(\approx 1 \%)$ & 5.415 \\
\hline Experiment -2- & 1320 & $30.12(\approx 2 \%)$ & 6.615 \\
\hline Experiment -3- & 1300 & $67.5(\approx 5 \%)$ & 8.615 \\
\hline Experiment -4- & 1350 & $150(\approx 11 \%)$ & 8.165 \\
\hline \multicolumn{3}{|c|}{ Mass of solvent } & \multirow{2}{*}{ Percentage of efficiency } \\
\hline & $\mathrm{CO}_{2}, \mathrm{~g}$ & Acetone, $\mathrm{g}$ & \\
\hline Experiment -1- & 1340 & $15.72(\approx 1 \%)$ & 4.95 \\
\hline Experiment -2- & 1320 & $30.12(\approx 2 \%)$ & 6.115 \\
\hline Experiment -3- & 1300 & $67.5(\approx 5 \%)$ & 8.115 \\
\hline \multirow[t]{3}{*}{ Experiment -4- } & 1350 & $150(\approx 11 \%)$ & 7.665 \\
\hline & \multicolumn{2}{|c|}{ Mass of solvent } & \multirow{2}{*}{ Percentage of efficiency } \\
\hline & $\mathrm{CO}_{2}$, g & Ethanol, g & \\
\hline Experiment -1- & 1340 & $15.72(\approx 1 \%)$ & 4.415 \\
\hline Experiment -2- & 1320 & $30.12(\approx 2 \%)$ & 5.615 \\
\hline Experiment -3- & 1300 & $67.5(\approx 5 \%)$ & 7.615 \\
\hline \multirow[t]{3}{*}{ Experiment -4- } & 1350 & $150(\approx 11 \%)$ & 7.165 \\
\hline & \multicolumn{2}{|c|}{ Mass of solvent } & \multirow{2}{*}{ Percentage of efficiency } \\
\hline & $\mathrm{CO}_{2}, \mathrm{~g}$ & Methanol, g & \\
\hline Experiment -1- & 1340 & $15.72(\approx 1 \%)$ & 3.915 \\
\hline Experiment -2- & 1320 & $30.12(\approx 2 \%)$ & 5.115 \\
\hline Experiment -3- & 1300 & $67.5(\approx 5 \%)$ & 7.115 \\
\hline \multirow[t]{3}{*}{ Experiment -4- } & 1350 & $150(\approx 11 \%)$ & 6.665 \\
\hline & \multicolumn{2}{|c|}{ Mass of solvent } & \multirow{2}{*}{ Percentage of efficiency } \\
\hline & $\mathrm{CO}_{2}, \mathrm{~g}$ & Chloroform, g & \\
\hline Experiment -1- & 1340 & $15.72(\approx 1 \%)$ & 3.415 \\
\hline Experiment -2- & 1320 & $30.12(\approx 2 \%)$ & 4.615 \\
\hline Experiment -3- & 1300 & $67.5(\approx 5 \%)$ & 6.615 \\
\hline Experiment -4- & 1350 & $150(\approx 11 \%)$ & 6.165 \\
\hline
\end{tabular}

- Ethanol

- Methanol

- Chloroform

First, the mass of the catalyst increases with the concentration of co-solvent and goes to a plateau, and further decreases. The maximum efficiency of the regeneration process corresponds to a co-solvent concentration equal to $5 \mathrm{wt} \%$ to $6 \mathrm{wt} \%$. Subsequent experiments on the regeneration of catalyst samples are conducted with this value of the concentration of co-solvent (5\%). The results of these studies are shown in Figure 6 and Figure 7.

As can be seen in Figure 7, the highest degree of extraction of deactivating compounds is obtained using dimethyl sulfoxide as a co-solvent. This solvent has a higher polarity (4.05 D) in comparison with other substances (chloroform-1.14 D, methanol-1.71 D, ethanol-2.28 D, acetone-2.7 D) [23], that allows a more complete extraction of polar compounds.

One of the main indicators characterizing the catalyst is its specific surface area [24]. According to the method of determining the specific surface area described above, this parameter was determined for the following samples:

- Pure alumina calcined for 3 hours at a temperature of $773 \mathrm{~K}$; 


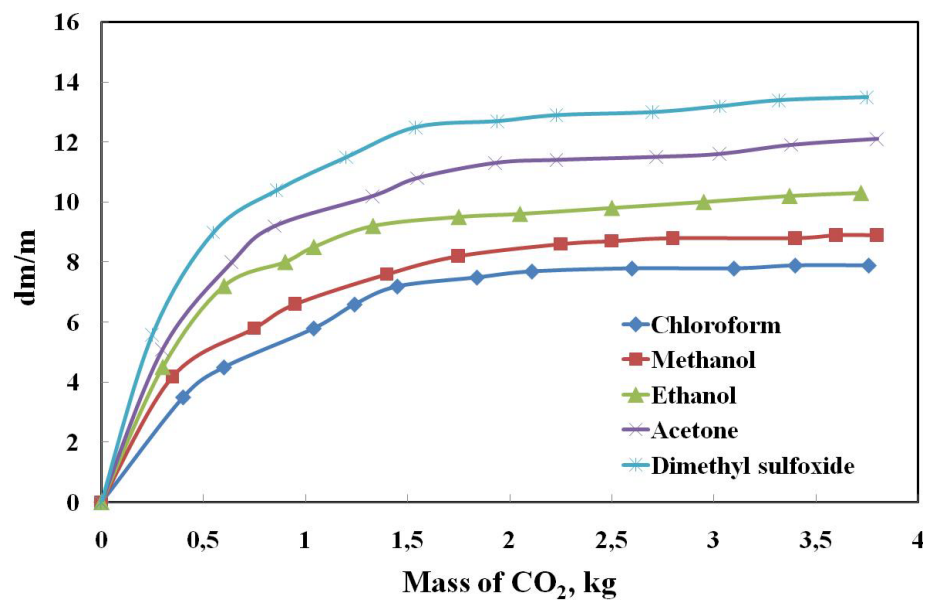

Figure 7. Change in the mass of catalyst sample sin there generation process of extraction by supercritical carbon dioxide with different co-solvents, at an optimal concentration of $5 \mathrm{wt} \%$, at $T=383 \mathrm{~K}$, and $P=30 \mathrm{MPa}$ in terms of the mass of carbon dioxide modified.

Table 6. Determination of the specific surface area for various catalyst samples.

\begin{tabular}{ccccccc}
\hline Sample & Scale & $\begin{array}{c}\text { Peakheight } \\
(\mathrm{mm})\end{array}$ & $\begin{array}{c}\text { Peakwidth } \\
(\mathrm{mm})\end{array}$ & $\begin{array}{c}\text { Peak area } \\
\left(\mathrm{mm}^{2}\right)\end{array}$ & $\begin{array}{c}\text { Volume of gas } \\
\left(\mathrm{cm}^{3}\right)\end{array}$ & $\begin{array}{c}\text { Specific surface area } \\
\left(\mathrm{m}^{2} / \mathrm{g}\right)\end{array}$ \\
\hline Purealumina & $1: 64$ & 123 & 4.2 & 337,920 & 0.105 & 182.0 \\
Spentcatalyst & $1: 32$ & 159 & 4.8 & 201,506 & 0.101 & 108.5 \\
Airregeneration & $1: 64$ & 100 & 3.5 & 217,475 & 0.103 & 117.1 \\
$\begin{array}{c}\text { Regeneration with } \\
\text { SC-CO }\end{array}$ & $1: 64$ & 124 & 4.2 & 317,440 & 0.105 & 170.9 \\
\hline
\end{tabular}

- A non-regenerated spent catalysts sample;

- A catalyst sample regenerated according to conventional techniques of coke burning during 2 hours at a temperature of $823 \mathrm{~K}$;

- A catalyst sample regenerated with a mixture of SC- $\mathrm{CO}_{2}$ and dimethyl sulfoxide at $T=363.15 \mathrm{~K}$ and $P=25$ Mpa.

The results of this study are shown in Table 6 .

The specific surface area $\left(\mathrm{m}^{2} / \mathrm{g}\right)$ is calculated by multiplying the scale, the peak height $(\mathrm{mm})$, the peak width (mm) given in Table 6, and the constant value of 0.0005385 for $\mathrm{Al}_{2} \mathrm{O}_{3}$, and dividing the result by the volume of gas $\left(\mathrm{cm}^{3}\right)$.

Catalyst sample regenerated with supercritical carbon dioxide, modified with dimethyl sulfoxide, has a specific surface area close to that of the pure aluminum oxide, which is not the case of the sample regenerated in air flow at $823 \mathrm{~K}$. Thus, the whole regeneration, and therefore its efficiency with the supercritical fluid approach, is significantly higher than with the conventional high temperature process.

\section{Conclusion}

Results of the conducted research show efficiency and attractiveness of $\mathrm{SC}-\mathrm{CO}_{2}$-regeneration process within a problem of catalysts deactivation. Increase of specific surface area of regenerated catalyst samples shows that extraction of deactivating compounds from catalyst surface was successful, and this in turn indirectly indicates on recovery of catalyst operating properties.

\section{Acknowledgements}

Authors of the present research express the gratitude to the Russian Scientific Fund (RSF) for financing of these researches within a grant 14-19-00749. 


\section{References}

[1] Rakhmanov, A. (2009) Technical Regulation < Requirements to Automobile and Aviation Gasoline, Diesel and Ship Fuel, Jet Engine Fuel and Furnace Boiler Oil>. Informal Document No. WP.29-148-1.

[2] Boreskov, G.K. (1971) Catalysis. Nauka Publisher, Novosibirsk, 267 p.

[3] Speight, J.G. (2000) The Desulfurization of Heavy Oils and Residua. Marcel Dekker Inc., New York.

[4] Satterfield, Ch. (1976) Practical Course of Heterogeneous Catalysis. Khimiya Publisher, Moscow, 240 p.

[5] Kutepov, A.M., Bondareva, T.M. and Berengarten, M.T. (2004) General Chemical Engineering: A Textbook for Technical Colleges. Academkniga Publisher, Moscow, 528 p.

[6] Mukhlenov, I.P., et al. (1984) General Chemical Technology. Volume 2, Most Important Chemical Production. Vysshaya Shkola Publisher, Moscow, 263 p.

[7] Parkash, S. (2003) Refining Process Handbook. Elsevier, Amsterdam.

[8] Gary, J.H., Handwerk, G.E. and Kaiser, M.J. (2007) Petroleum Refining: Technology and Economics. 5th Edition, CRC Press, Boca Raton, 488 p.

[9] Babich, I.V. and Moulijn, J.A. (2003) Science and Technology of Novel Processes for Deep Desulfurization of Oil Refinery Streams. Fuel, 82, 607-631. http://dx.doi.org/10.1016/S0016-2361(02)00324-1

[10] Javadli, R. and de Klerk, A. (2012) Desulfurization of Heavy Oil. Applied Petrochemical Research, 1, 3-19. http://dx.doi.org/10.1007/s13203-012-0006-6

[11] Steiner, P. and Blekkan, E.A. (2002) Catalytic Hydrodesulfurization of a Light Gas Oil over a NiMo Catalyst: Kinetics of Selected Sulfur Components. Fuel Processing Technology, 79, 1-12.

[12] Masagutov, R.M., Morozov, B.F. and Kutepov, B.I. (1987) Regeneration of Catalysts in Oil Refining and Petrochemicals. Chemistry Publisher, Moscow, 144 p.

[13] Kurganov, V.M., Kushner, V.E. and Agafonov, A.V. (1973) Steam-Air Regeneration of Hydrotreating Catalysts. TsNIITEneftehim Publisher, Moscow, 71 p.

[14] Krylov, O.V. (2004) Heterogeneous Catalysis: The Manual for Higher Schools. Akademkniga, Moscow, 679 p.

[15] Bilalov, T.R. and Gumerov, F.M. (2011) The Manufacturing Processes and Catalyst Regeneration/Thermodynamic Basis of Production Processes and Regeneration of Palladium Catalysts Using Supercritical Carbon Dioxide. LAP LAMBERT Academic Publishing GmbH \& Co. KG., Dudweiler Landstr., 153 p.

[16] Samakhov, A.A., Zaidman, N.M., Chizhik, M.D. and Buyanov, R.A. (1976) Changes of Catalyst Activity during Service. Nauka Publisher, Novosibirsk, 108 p.

[17] Brunauer, S., Emmett, P.H. and Teller, E. (1938) Adsorption of Gases in Multi Molecular Layers. Journal of the American Chemical Society, 60, 309-319.

[18] Dimbat, M., Porter, P.E. and Stross F.H. (1956) Apparatus Requirements for Quantitative Applications. Journal of the American Chemical Society, 28, 290-297.

[19] Gumerov, F.M., Sabirzyanov, A.N. and Gumerova, G.I. (2007) Sub- and Supercritical Fluids in Polymer Processing. Fen Publisher, Kazan, 336 p.

[20] Bilalov, T.R., Gumerov, F.M., Gabitov, F.R., Kharlampidi, K.E., Fedorov, G.I., Sagdeev, A.A., Yarullin, R.S. and Yakushev, I.A. (2009) The Synthesis and Regeneration of Palladium Catalysts with the Use of Supercritical Carbon Dioxide. Russian Journal of Physical Chemistry B, 3, 80-92.

[21] Tyapkin, E.V., Sharafutdinov, I.R. and Gumerov, F.M. (2006) Regeneration of PU Brand Palladium Catalyst with the Use of Supercritical Extraction Process. Proceedings of the III International Scientific and Practical Conference "Supercritical Fluid Technologies: The Innovative Potential of Russia”, Rostov, 67-69.

[22] Galimova, A.T., Sagdeev, A.A. and Gumerov, F.M. (2013) Research of Solubility of Substances Deactivating Catalyst Oxide of Aluminum Possessing Activity in Supercritical Carbon Dioxide. Proceedings of the Higher Educational Institutions, Series of Chemistry and Chemical Engineering, 56, 65-68.

[23] Knunyants, I.L. (1988) Chemical Encyclopedia. Volume 1, Sovietswkayaenciklopediya Publisher, Moscow, 623 p.

[24] Sánchez-Delgado, R.A. (2002) Organometallic Modeling of the Hydrodesulfurization and Hydrodenitrogenation Reactions. Springer Science \& Business Media, New York, 209 p. 